\title{
BELAJAR DARI KECERDASAN LOKAL: STUDI TENTANG KAMPUNG NAGA
}

\author{
Pancawati Dewi \\ Program Magister Arsitektur, Universitas Gunadarma, \\ Jl. Margonda Raya No. 100, Pondok Cina, Depok, 16424 \\ Email: pancawati_dewi@staff.gunadarma.ac.id
}

\begin{abstract}
Abstrak
Perubahan yang terjadi pada rumah tinggal masyarakat Kampung Naga tidak bisa dihindarkan. Perubahan disesuaikan dengan perkembangan jaman menyesuaikan dengan kondisi sosial ekonomi dan budaya yang berkembang. Metode yang digunakan pada penelitian ini adalah InterpretiveHistorical. Kunci dari metode penelitian ini adalah interpretasi. Hal ini dilakukan untuk mencoba memahami fenomena yang ada di lapangan (sebuah kelompok masyarakat yang subyektif) dan membawanya kepada interpretasi yang obyektif. Perubahan tata letak dan material rumah tidak dapat dihindarkan guna menyesuaikan adanya kebutuhan baru dan teknologi masa kini. Perubahan pola tatanan rumah tinggal dan adanya penambahan ruang baru menunjukkan keramahan dan keterbukaan masyarakat Kampung Naga dalam menyambut wisatawan. Adapun upaya untuk tetap melestarikan tradisi mereka menunjukkan kuatnya jati diri masyarakat di Kampung Naga dalam menghadapi perubahan jaman. Perletakan perapian saat ini cenderung tetap, meskipun dapat mengalami pergeseran letak. Perapian yang memiliki peran penting dalam kehidupan sehari-hari masyarakat kampung Naga dari dahulu kala mampu dijaga keberlangsungannya hingga hari ini.
\end{abstract}

Kata kunci: ruang, hawu, perubahan, keberlangsungan.

\begin{abstract}
Title: Learning from the Local Intelligence: Study in Kampung Naga

Changes that occur in Kampung Naga houses can not be avoided. Change is adapted to the development of the times adjusting to the evolving socio-economic and cultural conditions. The method used in this study is the Interpretive-Historical. The key to this research method is interpretation. This is done to try to understand the phenomena that exist in the field (a subjective group of people) and bring them to an objective interpretation. Material changes to the layout and the house can not be avoided in order to customize their new needs and technology of today. Changing patterns of house structure and the addition of new space shows the friendliness and openness of Kampung Naga society in welcoming the tourists. The effort to preserve their traditions still shows strong identity in Kampung Naga society in the face of changing times. Placement the hearth at this time is tend to be permanent, though it can be shifted layout. The hearth has an important role in people's daily lives in Kampung Naga since old time to be maintained to this day.
\end{abstract}

Keywords: space, hawu, change, sustainability.

\section{Pendahuluan}

Di dalam pembelajaran teori tentang ruang (space), api memiliki posisi yang cukup sentral. Seperti yang disampaikan Unwin (1997), perapian adalah salah satu bentuk arsitektur awal atau tempat primitif yang telah dikenal sejak lama. Sedangkan Westcott (Eds., 2014) menyatakan 
bahwa perapian menjadi salah satu elemen arsitektur yang sangat penting dengan segala perubahan dan pergeseran yang terjadi saat ini. Pada beberapa masyarakat masa kini yang masih kuat memegang tradisi, jejak dari api masih bisa dilacak. Begitu pentingnya perapian bagi masyarakat nusantara, sehingga elemen dasar yang paling mudah ditemukan pada interior rumah nusantara dari dahulu hingga sekarang adalah jejak perapian.

Menurut Dewi (2011), api selain dapat dimanfaatkan melalui fungsinya berdasarkan unsur-unsur fisik yang dimiliki api dapat dimanfaatkan oleh manusia melalui unsur non fisiknya. Sebagai genesis (asal-usul), tak salah apabila api kemudian dianggap suci (sakral) oleh manusia. Kepercayaan akan api merupakan kepercayaan yang berusia tua, melalui proses yang terus berkembang. Api berubah dari benda fisik menjadi metafisik, dari benda natural menjadi benda supranatural. Dari api menjadi Dewa Api atau Dewa penjaga api.

Dewi, Budiyanto, Safeyah dan Hasan R. (2016) juga menyatakan, faktor yang berpengaruh terhadap keajegan dan perubahan pada perapian nusantara tidak hanya disebabkan oleh aspek geografi, tetapi juga aspek sosial budaya. Kasus arsitektur di Nusantara memperlihatkan, perapian tidak dapat dipisahkan dari kehidupan masyarakat setempat. Seperti yang dijelaskan oleh Dewi, Trilita dan Safeyah (2017), tentang beberapa wilayah yang masih memegang tradisi lama berusaha untuk mempertahankan seperti kondisi awalnya, namun tidak sedikit juga yang berhasil melakukan inovasi dengan melakukan perubahan tanpa mengurangi makna. Tempat untuk meletakkan perapian pada rumah masyarakat Nusantara tidak boleh sembarangan dan kadang malah bersifat sakral.

Kent (1990) dalam teorinya tentang penggunaan ruang menjelaskan mengenai penggunaan perapian dalam beberapa masyarakat tertentu. Kent mengklasifikasikan masyarakat berdasarkan pada kompleksitas sosiopolitik, spesialisasi ekonomi dan perbedaan pekerjaan. Semakin kompleks sebuah masyarakat maka perapian yang digunakan akan semakin beragam. Semakin kompleks sebuah masyarakat maka budaya, lingkungan, penggunaan ruang, material lokal (yang terkait budaya) dan arsitekturnyapun akan semakin terbagi (tersegmentasi).

Pendekatan fungsional Johnston dan Gonlin (1998) menggunakan variabel sosioekonomi untuk melihat struktur sebuah rumah. Pada rumah tangga miskin, struktur tunggal sebuah rumah akan mengakomodasi berbagai aktivitas yang berbeda (tidur, makan, upacara agama dll). Sedangkan semakin kaya rumah tangganya (dari sisi ekonomi) maka struktur rumah semakin kompleks atau secara ilmu bangunan akan terdapat ruang yang berbeda sesuai dengan masing-masing aktivitas yang berbeda pula.

Adapun pengaturan ruang menurut Tzortzi (2007), merupakan komponen dari model ruang yang akan menyiratkan pengakomodasian pergerakan yang terjadi dan penataan (lay out) perabot. Pola pergerakan antara ruang satu ke ruang yang lain, menimbulkan suatu pola pergerakan. Pola pergerakan antara penghuni satu dengan penghuni lain akan terdapat kesamaan dan perbedaan tergantung pada fungsi ruang, kebutuhan dan kebiasaan individu. Pola pergerakan akan berubah bila pengaturan ruang 
berubah, seperti bila terjadi penambahan ruang, ruang yang dibesarkan, ruang dirubah tampilannya, ruang dirubah fungsinya, dan seterusnya.

Teori-teori tersebut selanjutnya akan digunakan untuk membaca fenomena di lapangan penelitian. Menurut Suganda (2006) dan Sarigendyanti (2008) dalam Permana (2015), secara tradisional tata guna atau kawasan lahan di Kampung Naga terbagi 3 kawasan yaitu (1) kawasan suci, (2) kawasan bersih dan (3) kawasan kotor. Kawasan yang disucikan oleh penduduk Kampung Naga merupakan bukit kecil yang berada di sebelah barat permukiman Kampung Naga. Kawasan bersih merupakan permukiman penduduk dengan luas 1,5 ha yang terdiri dari rumah-rumah (imah), masjid, bale patemon (tempat pertemuan), bumi ageung dan bangunan leuit. Kawasan kotor adalah kawasan yang peruntukannya sebagai kelengkapan hidup lainnya yang tidak perlu dibersihkan setiap saat. Kawasan kotor berada pada daerah yang permukaan tanahnya lebih rendah. Kawasan tersebut terletak bersebelahan dengan sungai Ciwulan.

Kampung Naga berpola kampung dengan tanah lapang di tengah-tengah kampung. Adapun fungsi dari tanah lapang ini salah satunya adalah untuk tempat penyelenggaraan upacara yang menyangkut kepentingan warga kampung. Rumah-rumah terletak di kiri dan kanan tanah lapang secara berderet ataupun mengelompok. Selain rumah tinggal, di kampung ini juga dilengkapi dengan fasilitas tempat ibadah dan balai pertemuan. Terbatasnya wilayah permukiman di Kampung adat membuat sebagian masyarakat membangun permukiman baru di wilayah atas dari Kampung
Naga (adat). Kampung yang baru ini terletak di pintu masuk menuju Kampung Adat. Selain rumah tinggal, di Kampung Baru ini juga berkembang fasilitas lainnya seperti fasilitas perdagangan (toko suvenir dan rumah makan) yang mendukung kegiatan pariwisata di wilayah ini. Perkembangan Kampung Naga sebagai salah satu obyek wisata juga mempengaruhi terhadap pola tatanan ruang di kampung adat. Munculnya aktifitas baru memberikan konsekuensi hadirnya ruang baru.

\section{Metode Penelitian}

Penelitian di Kampung Naga ini dilakukan pada tahun 2016 dengan menggunakan dana Hibah Kompetensi Tahun Kedua dari Ristekdikti. Adapun metode penelitian yang di gunakan pada penelitian ini adalah metode Interpretive-Historical menurut Groat dan Wang (2002). Metode penelitian ini melibatkan data-data kesejarahan yang dilakukan dengan cara mencari data/fakta/kejadian; mengkoleksi dan mengorganisasi data; mengevaluasi dan mengkonstruksinya ke dalam sebuah narasi secara holistik dan dapat dipercaya. Kunci dari metode penelitian ini adalah interpretasi. Hal ini dilakukan untuk mencoba memahami fenomena yang ada di lapangan (sebuah kelompok masyarakat yang subyektif) dan membawanya kepada interpretasi yang obyektif.

Penelitian sebelumnya tentang perapian di Tengger dan di tempat lain di nusantara menjadi titik tolak dalam memahami fenomena di Kampung Naga. Pengamatan dan dokumentasi di lapangan dilakukan guna mendapatkan gambaran umum tentang tatanan ruang dalam rumah di Kampung Naga dan penggunaan perapian di dalam rumah. 
Data sekunder atau referensi tentang Kampung Naga yang ada di gunakan untuk membantu peneliti memahami kondisi di lapangan dan melengkapi data-data terutama data tentang kesejarahan.

\section{Hasil dan Pembahasan}

\section{Tatanan Ruang Dalam}

Tatanan ruang dalam pada rumah asli masyarakat Kampung Naga yang tinggal di kawasan adat, memiliki satu dapur; satu goah (tempat menyimpan padi atau gabah hasil panen dari keluarga tersebut); satu sepen (ruang tidur orang tua); dan satu tengah imah (ruang tengah). Pada gambar 1 memperlihatkan denah rumah asli dengan satu pintu masuk ke dalam yang langsung mengarah ke dapur. Pada rumah asli kegiatan menerima tamu, makan, bersosialiasi terpusat di area sekitar hawu.

Semenjak Kampung Naga dijadikan obyek tujuan wisata, banyak wisatawan baik domestik maupun mancanegara yang datang, bahkan ada yang tinggal selama beberapa hari dengan cara menginap di rumah-rumah mereka. Adanya kegiatan baru yaitu menerima kunjungan tamu wisatawan bahkan menginap di rumah masyarakat maka rumah tinggal atau imah masyarakat Kampung Naga (kampung adat) saat ini sudah mengalami perubahan. Perubahan tersebut antara lain: a). penambahan jumlah sepen atau ruang tidur, b). penambahan ruang baru yang sebelumnya tidak ada yaitu tepas atau ruang khusus untuk menerima tamu, dan c). penambahan pintu masuk ke dalam rumah yang langsung mengarah ke tepas.

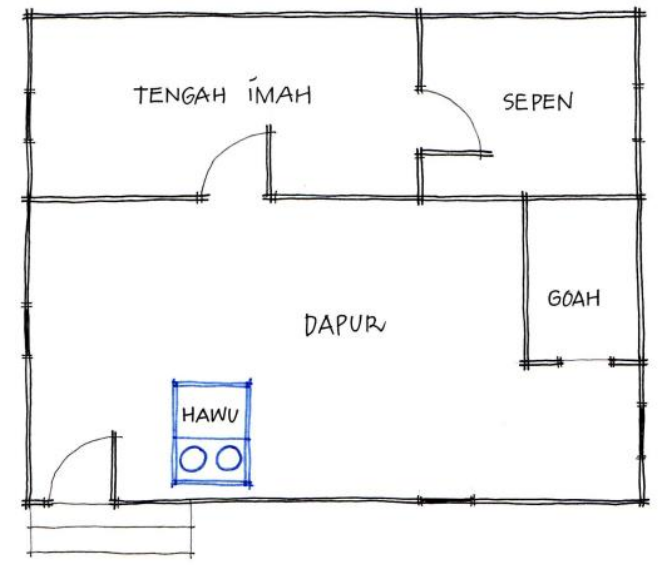

\section{Gambar 1. Tatanan ruang dalam pada rumah (asli) di Kampung Naga (adat) Sumber: Dokumentasi penulis, 2016}

Gambar 2 di bawah memperlihatkan, salah satu rumah yang sudah mengalami perubahan. Rumah ini memiliki satu dapur; satu goah; satu tepas; tiga sepen dan satu tengah imah. Penambahan jumlah sepen dilakukan untuk menampung kebutuhan tamu/wisatawan yang datang menginap. Sepen yang awalnya berjumlah satu bertambah menjadi dua atau tiga, hal ini dapat dipengaruhi oleh kemampuan sosial ekonomi penghuni dan kebutuhan yang ada. Selain itu, terjadi penambahan jumlah pintu masuk ke dalam rumah di bagian tepas. Rumah tinggal masyarakat Kampung Naga di kawasan adat saat ini dominan dengan rumah yang sudah mengalami perubahan, yaitu rumah dengan dua pintu masuk dan memiliki tepas. Bahkan rumah asli yang hanya memiliki satu pintu sudah mulai jarang di temukan di kampung ini. 


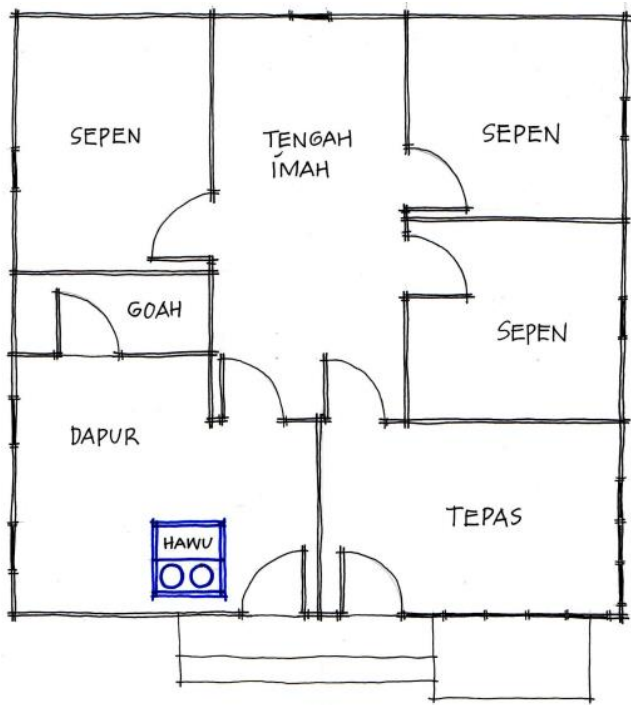

Gambar 2. Tatanan ruang dalam pada rumah di Kampung Naga (adat) yang sudah mengalami perubahan

Sumber: Dokumentasi penulis, 2016

Bangunan rumah tinggal masyarakat Naga di kampung baru juga masih mempertahankan tradisi rumah asli mereka dengan sedikit melakukan perubahan sesuai dengan kebutuhan mereka. Pola hunian cenderung masih mengikuti pola hunian rumah asli, meskipun ada salah satu obyek kasus yang memperlihatkan adanya perubahan yaitu hilangnya ruang tengah/imah. Seperti diperlihatkan pada gambar 3, menunjukkan kedekatan dapur (tempat meletakkan hawu) dengan goah. Rata-rata pintu masuk rumah di kampung baru ini sebanyak dua pintu, satu pintu masuk menuju dapur sedangkan pintu yang lain langsung masuk ke tepas.

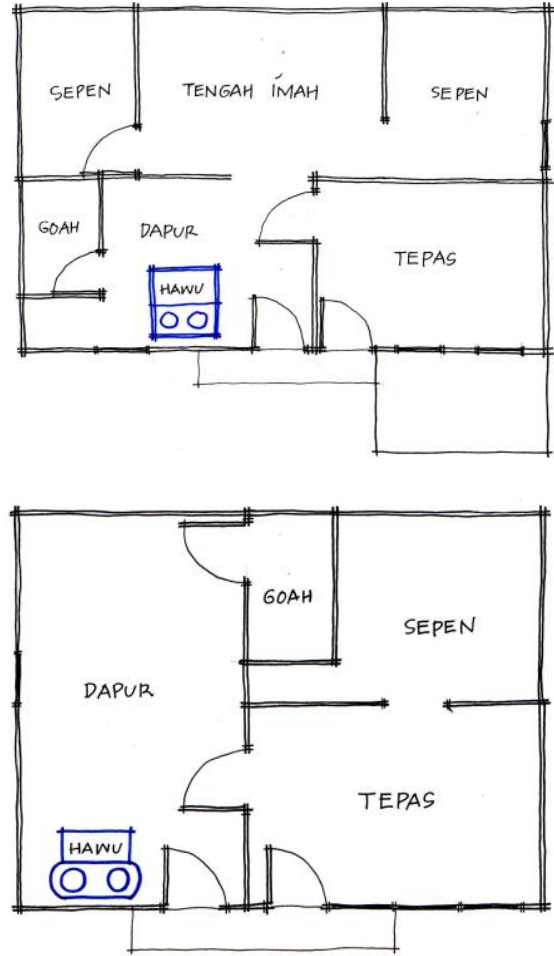

Gambar 3. Tatanan ruang dalam pada rumah di Kampung Naga (baru)

Sumber: Dokumentasi penulis, 2016

Perbedaan pada ruangan ini dibandingkan dengan dapur pada rumah asli atau yang ada di kampung adat biasanya adalah pada penggunaan material bangunan baik pada lantai bangunan hingga bahan dinding semuanya menggunakan bahan anyaman bambu, atap dari ijuk, sedangkan dinding rumah menggunakan bahan kayu dan anyaman bambu. Sedangkan rumah di kampung baru menggunakan bahan bangunan yang lebih beragam dengan bentuk jendela dan warna bangunan yang lebih modern.

Adanya perubahan atau perkembangan pada pola tatanan ruang dalam baik yang di kampung adat maupun kampung baru menunjukkan bahwa imah Kampung Naga mampu beradaptasi terhadap perubahan jaman. Seperti pernyataan Kent (1990) dan Johnston \& Gonlin (1998), semakin 
kompleks kondisi sosial ekonomi dan budaya sebuah masyarakat maka ruang dalam juga akan semakin tersegmentasi atau kompleks juga.

\section{Orientasi}

Semua bangunan di Kampung Naga memiliki bubungan atap yang memanjang ke arah barat-timur, dengan pintu di bagian panjang bangunan yaitu sisi utara-selatan. Posisi rumah di kawasan adat ini saling berhadapan dengan orientasi ke utara atau selatan. Posisi rumah yang saling berhadapan ini dilakukan untuk saling menjaga, baik terhadap keamanan dari kejahatan maupun bahaya kebakaran dari perapian di dalam rumah, mengingat material rumah adalah bahan alami yang mudah terbakar, seperti yang terlihat pada gambar 4 .

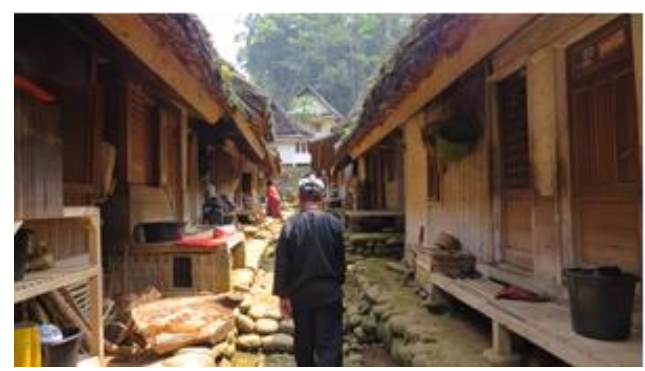

Gambar 4. Posisi rumah yang saling berhadapan di Kampung Naga (adat) Sumber: Dokumentasi penulis, 2016

\section{Dapur}

Selain fungsi utamanya sebagai tempat memasak, dapur merupakan ruangan yang serba guna. Dapur atau pawon dapat berfungsi sebagai tempat makan bersama dan sering juga digunakan sebagai tempat mengobrol. Kadang kaum pria menghangatkan badan di dekat hawu pada waktu subuh sebelum ke kebun atau sawah, atau pada saat udara dingin. Sahabat atau tetangga yang sudah cukup dekat seringkali diundang juga ke dapur jika sedang bertamu. Sedangkan tamu jauh atau wisatawan lebih sering diterima di tepas.

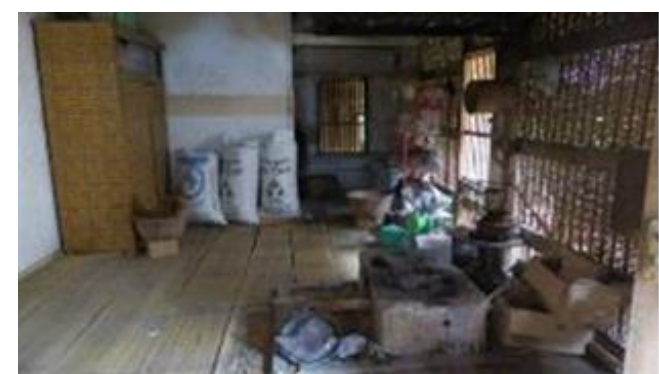

Gambar 5. Dapur sebagai tempat meletakkan hawu pada rumah dengan satu pintu masuk

Sumber: Dokumentasi penulis, 2016

Bahkan pada rumah asli masyarakat kampung Naga (yang hanya memiliki 1 pintu masuk), area menerima tamu selalu didekatkan dengan hawu. Sehingga area di dapur cukup luas, selain sebagai tempat untuk meletakkan peralatan memasak juga tersedia cukup luas untuk area menerima tamu (gambar 5).

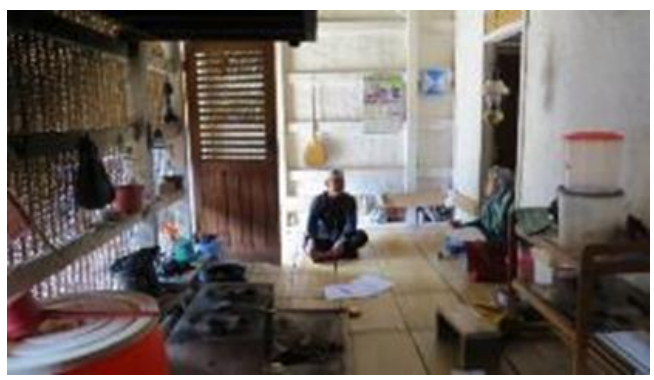

Gambar 6. Dapur sebagai tempat meletakkan hawu pada rumah dengan dua pintu masuk

Sumber: Dokumentasi penulis, 2016

Dapur sebagai ruang untuk memasak sekaligus ruang serba guna pada hunian masyarakat Naga di kampung baru berfungsi relatif sama dengan masyarakat yang tinggal di kampung adat. Kegiatan sehari-hari semua anggota keluarga terpusat di ruangan ini (gambar 7). 


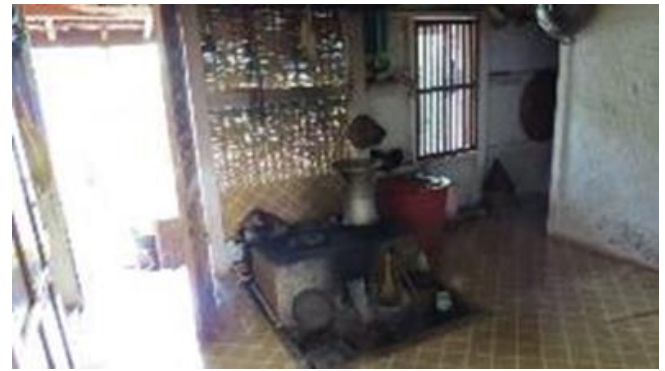

Gambar 7. Dapur masyarakat Naga di Kampung Baru

Sumber: Dokumentasi penulis, 2016

Material atau bahan bangunan yang digunakan di dapur (tepat di belakang hawu) biasanya menggunakan dinding dan pintu yang terbuat dari anyaman bambu. Dinding berpori menjadi pilihan yang tepat guna untuk memudahkan sirkulasi asap akibat proses pembakaran di hawu keluar rumah. Sedangkan daun pintu yang juga berpori dibuat untuk menjaga keamanan rumah.

Pintu dapur dari arah luar rumah dibuat transparan akan memudahkan tetangga atau orang dari luar pada malam hari ikut memantau seandainya pemilik rumah lupa mematikan api di hawu yang dapat berpotensi menimbulkan bahaya kebakaran. Selain perlindungan terhadap bahaya perapian yang dapat dipicu dari perapian (hawu) di dalam rumah dilakukan melalui disain pintu dapur. Keamanan dari dalam rumah dengan pintu yang berpori memungkinan si pemilik rumah mengetahui orang yang akan berkunjung sebelum membuka pintu.

Dapur sebagai pusat kegiatan di dalam rumah di Kampung Naga memperkuat penelitian penulis sebelumnya. Perapian (hawu) masih memiliki posisi yang cukup sentral atau penting di Kampung Naga, seperti yang disampaikan Unwin (1997) dan Wescott (Eds., 2014) meskipun perletakannya tidak di tengah-tengah ruangan.

\section{Hawu}

Untuk memasak, di dapur ibu menggunakan tungku tanah liat atau hawu. Bahan bakar yang berupa kayu dan bambu dari kebun atau hutan disimpan di para seuneu. Para seuneu yang ada di atas hawu ini juga digunakan untuk menyimpan dan mengeringkan persediaan makanan atau bumbu masakan dan tempat memanggang tempat nasi (baboko).

Bentuk hawu atau tungku perapian di rumah masyarakat Kampung Naga khususnya yang ada di kampung adat ini relatif memiliki bentuk dan ukuran yang hampir sama. Hawu memiliki dua lubang atas yang diguakan untuk memasak dan satu lubang samping untuk memasukkan bahan bakar (kayu). Ukuran hawu bervariasi antara $75 \mathrm{~cm}$ x $80 \mathrm{~cm}$ sampai dengan $100 \mathrm{~cm} \mathrm{x}$ $115 \mathrm{~cm}$ (gambar 8).
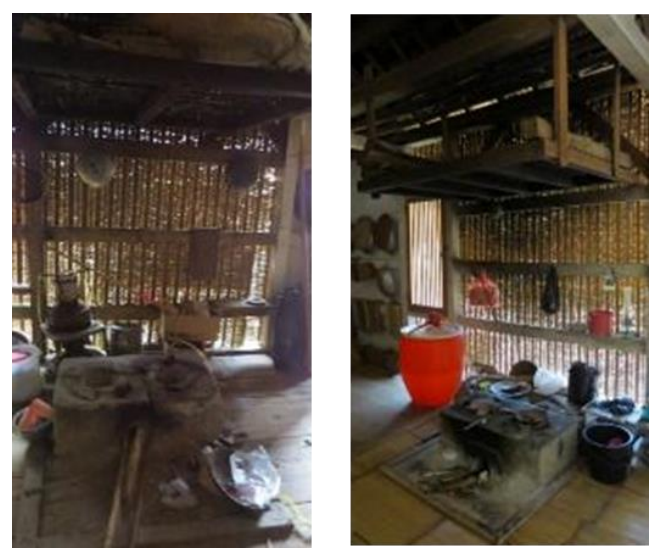

Gambar 8. Hawu atau tungku perapian di Kampung Naga (permukiman adat) Sumber: Dokumentasi penulis, 2016

Bentuk hawu pada rumah hunian di kampung baru ini relatif memiliki bentuk yang sama dengan aslinya. Hawu masih dibingkai dengan kayu untuk memisahkan tempat bara dengan lantai dapur. Sedangkan di atas hawu 
masih terdapat para seuneu yaitu tempat untuk menyimpan bahan bakar yang berupa kayu dan bambu (gambar 9). Material bangunan terutama pada lantai dapur yang terbuat dari kayu dan bambu merupakan bahan yang cenderung mudah terbakar, sehingga perletakan hawu tidak boleh sembarangan. Bentuk hawu dibuat sedemikian rupa dengan memperhatikan keamanan dari sifatnya yang mudah terbakar. Hawu dibingkai dengan bahan kayu yang diberi pasir supaya bara hasil pembakaran tidak membakar lantai papan atau palupuh yang disebut dengan parako.
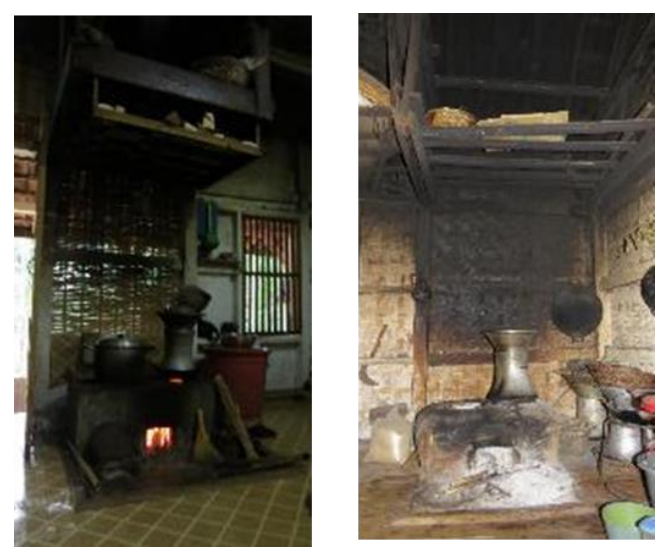

Gambar 9. Hawu atau tungku perapian di Kampung Naga (permukiman baru) Sumber: Dokumentasi penulis, 2016

Rumah Kampung Naga yang berbentuk rumah panggung dengan menggunakan bahan bangunan kayu dan bambu bersifat mudah terbakar. Oleh karena itu bentuk perlindungan terhadap hawu selain melalui bingkai kayu agar tidak mudah membakar lantai rumah juga dilakukan dengan membuat platform ke bawah. Platform tersebut dibuat dengan memiliki struktur tersendiri yang diletakkan di atas batu agar mampu menyangga beban dari hawu yang cukup berat.

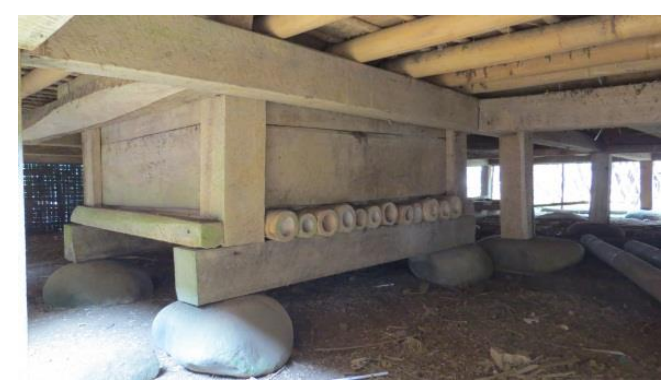

\section{Gambar 10. Paroko untuk meletakkan hawu}

Sumber: Dokumentasi penulis, 2016

Hawu yang relatif bersifat tetap dari bentuk, ukuran dan jumlah baik yang ada di kampung adat maupun kampung baru memperlihatkan usaha pelestarian atau tradisi yang dipertahankan. Sedangkan perletakan bisa bergeser namun selalu berada di dekat goah. Hal ini menunjukkan bahwa perapian di Kampung Naga (hawu) tidak banyak mengalami perubahan. Hal ini berbeda dengan kasus di Nusantara lainnya (Tengger, Sasak, Bali) yang sudah mengalami perubahan khususnya pada jumlah perapian.

\section{Goah}

Goah adalah ruang yang masih ditemui di setiap rumah masyarakat Naga di Kampung Naga dengan perletakan yang berdekatan dengan letak hawu di dapur. Memasak, khususnya menanak nasi, berhubungan erat dengan ritual wanita karena diasosiasikan dengan Dewi Sri. Penghormatan kepada Dewi Sri dapat terlihat dalam perletakan goah yang dianggap sebagai ruang utama sebuah rumah. Di dalam goah diletakkan sesaji untuk Dewi Sri setiap hari Selasa dan Jumat. Menyimpan padi dan beras seperti ini bukan sekedar menyimpan bahan makanan, melainkan juga memelihara dan melestarikan salah satu warisan leluhur. 
Sebagai ruang yang cukup sakral maka tidak boleh sembarangan orang masuk atau melihat ke dalam goah. Biasanya hanya kaum perempuan atau ibu yang boleh melihat atau masuk ke dalam goah. Selain itu, karena gabah atau padi yang belum ditumbuk diletakkan begitu saja di lantai goah maka untuk melindungi hasil panen tersebut dasar dari pintu goah dibuat tinggi atau pintu tersebut tidak langsung berada di atas permukaan lantai kecuali di kampung baru beberapa pintu goah sama dengan pintu ruangan yang lain (gambar 11). Daun pintu goah juga bermacammacam, ada yang menyesuaikan dengan pintu masuk dapur (dihiasi dengan anyaman bambu) atau pintu yang terbuat dari papan kayu seperti pintu ruangan yang lain.
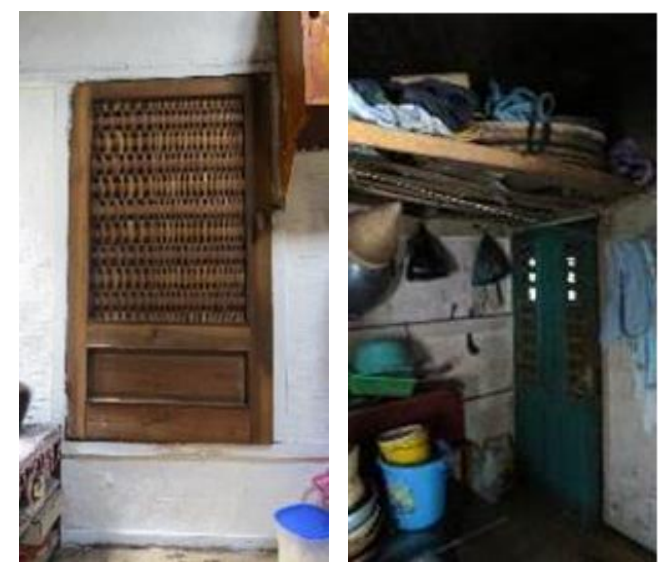

Gambar 11. Goah pada rumah masyarakat Kampung Naga - kampung adat (kiri) dan goah pada rumah masyarakat Kampung Naga - kampung baru (kanan) Sumber: Dokumentasi penulis, 2016

\section{Simbol}

Secara umum penduduk Kampung Naga memeluk agama Islam. Namun ajaran agama Islam yang dijalankan oleh penduduk Kampung Naga merupakan ajaran agama Islam yang telah mengalami pembauran dengan kepercayaan setempat. Sebagaimana masyarakat Sunda di pedesaan Jawa Barat pada umumnya, masyarakat
Kampung Naga juga mempercayai adanya hari baik dan buruk. Sebelum mengerjakan atau melaksanakan pekerjaan penting dalam lehidupan harus dihitung hari yang tepat agar terhindar dari kesialan dan memberikan hasil yang baik seperti pindah rumah, perkawinan, perhitungan jodoh, menanam padi dan memanen padi.
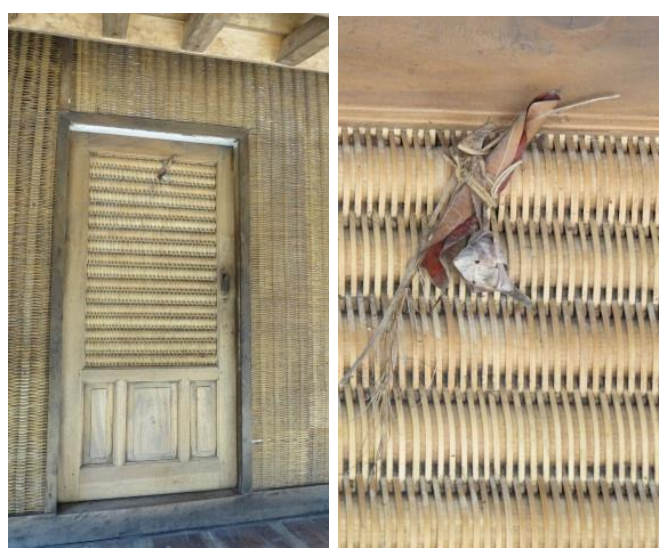

Gambar 12. Tulak bala

Sumber: Dokumentasi penulis, 2016

Selain mempercayai hari baik dan buruk, masyarakat Kampung Naga juga mempercayai adanya makhluk halus yang menghuni lubuk-lubuk sungai paling dalam, pohon-pohon yang besar dan tempat-tempat yang dianggap angker atau keramat. Karena itu untuk menjaga permukiman dari gangguan roh jahat, mereka memasang kandang jaga. Penjagaan dari gangguan roh jahat ini tidak hanya sebatas pada pemasangan kandang jaga saja, tetapi juga memasang tulak bala yang lazim dipasang di atas pintu rumah (gambar 12).

Kepercayaan yang lain adalah tidak boleh membicarakan masalah adat (pamali) yaitu pada hari Selasa, Rabu dan Sabtu. Hal ini berbeda dengan proses pembuatan tungku perapian (hawu) yang hanya boleh dilaksanakan pada hari Selasa. Hal ini menunjukkan, 
hawu merupakan elemen interior rumah yang sangat penting sehingga untuk proses pembuatannya saja harus dilakukan pada hari tertentu.

Perletakan goah selalu dekat dengan dapur dan sejajar dengan sepen (orang tua). Bahkan posisi tidur orang tua di dalam sepen dihadapkan ke goah atau kaki orang tua pada posisi tidur dekat dengan goah. Goah diletakkan di sisi barat atau timur sesuai weton atau hari kelahiran istri. Selain selalu berdekatan dengan ruangan yang paling sakral di dalam rumah (goah), nilai penting dari dapur di dibandingkan dengan ruangan yang lain adalah diletakkannya simbol tulak bala hanya di pintu dapur (gambar 13). Hal ini menunjukkan nilai penting sebuah dapur dengan hawu di dalamnya pada rumah masyarakat Naga.

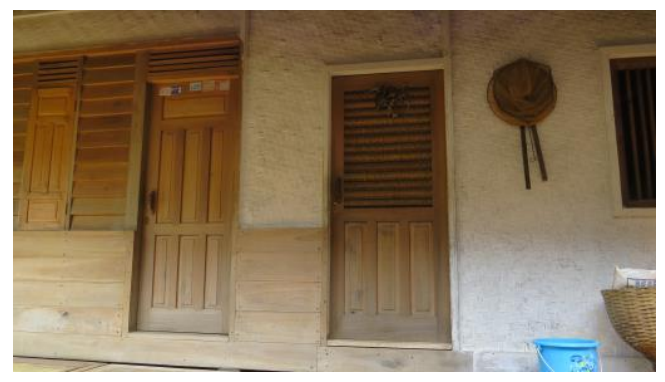

Gambar 13. Tulak bala yang terpasang di pintu dapur

Sumber: Dokumentasi penulis, 2016

\section{Kesimpulan}

Di kawasan kampung adat khususnya, ruang yang khusus untuk menerima tamu (tepas) adalah salah satu bukti munculnya ruang baru akibat adanya wisatawan yang berkunjung. Bertambahnya jumlah ruang tidur (sepen) juga dilakukan untuk memenuhi kebutuhan akan wisatawan yang sebagian datang untuk menginap. Adapun berubahnya sebagian fungsi rumah sebagai tempat kegiatan ekonomi (berjualan souvenir) juga bukti dampak dari berkembangnya Kampung Naga sebagai salah satu daerah tujuan wisata di Jawa Barat.

Perubahan tatanan ruang dalam pada rumah di Kampung Naga ini menegaskan kembali teori Kent (1990) tentang semakin kompleks kondisi sosial ekonomi dan budaya sebuah masyarakat maka ruang dalamnya juga akan semakin terbagi-bagi.

Selain perubahan yang terjadi pada tatanan ruang dalam di Kampung Naga, tungku perapian (hawu) cenderung tidak mengalami perubahan baik pada bentuk, letak, ukuran dan fungsinya. Perubahan pada perapian (hawu), biasanya terjadi pada pergeseran letak dari hawu karena adanya penambahan ruang yang baru (tepas) pada rumah mereka.

Hasil studi di Kampung Naga ini memperkaya tulisan penulis sebelumnya (Dewi, Budiyanto, Safeyah dan Hasan R., 2016; Dewi, Trilita dan Safeyah, 2017) tentang perapian di Nusantara. Perapian di Kampung Naga cenderung lebih bersifat ajeg selain itu hawu dengan nilai sakralnya memperkuat temuan Dewi (2011), tentang unsur non fisik dari sebuah perapian.

Belajar dari kecerdasan lokal, meskipun terjadi perubahan pada tatanan rumah mereka, keajegan yang diperlihatkan jauh lebih besar. Keyakinan masyarakat Kampung Naga akan tradisi leluhur yang dijunjung tinggi membuat keberlangsungan tradisi masyarakat dalam membangun dan merawat rumah mereka masih dapat disaksikan hingga hari ini. Meneruskan tradisi bukan berarti menolak perubahan. Masyarakat Kampung Naga terbukti mampu beradaptasi terhadap perubahan jaman 
sesuai dengan nilai-nilai masyarakat yang dimiliki.

Kecerdasan masyarakat Naga juga diperlihatkan melalui bentuk perlindungan dari hawu yang dilakukan untuk menghindari terbakarnya material bangunan akibat proses pembakaran yang ada. Selain itu, disain pintu dapur dan dinding dapur tepat di belakang perletakan hawu di buat dari anyaman bambu yang transparan sehingga memudahkan asap keluar dari rumah dan pengawasan dari luar rumah. Hal ini merupakan pengetahuan yang dapat digunakan untuk menghindari seringnya terjadi kebakaran terutama yang melanda kampung adat terutama yang diakibatkan oleh penggunaan perapian di dalam rumah.

\section{Daftar Pustaka}

Dewi, P. (2011). Peran perapian dalam rumah tinggal masyarakat Tengger, studi kasus: Desa Ngadisari Tengger (Disertasi S3, ITS, 2011. Tidak dipubikasikan).

Dewi P., Budiyanto H., and Safeyah M., Hasan R. (2016). The concept of hearth to legitimize nusantara architecture in Indonesia. Traditional Dwellings and Settlements Working Paper, Series Titles 2016-2017 Vol. 278. Berkeley USA: IASTE University of California.

Dewi P., Trilita, M.N. \& Safeyah, M. (2017). Genealogy of hearth in nusantara house. DIMENSI Journal of Architecture and Built Environment, Vol. 44 No. 2 Desember 2017, hal. 111-116.

Groat, L. \& Wang, D. (2002). Architectural research methods. Hoboken: John Wiley \& Sons, Inc., USA.
Johnston \& Gonlin. (1998). Function and meaning in classic maya architecture. Washington, DC: Dumbarton Oaks Research Library and Collection.

Kent, S. (1990). A cross-cultural study of segmentation architecture, and the use of space. Dalam Kent, S. (Ed.), Domestic architecture and the use of space. Cambridge University Press, 127-152.

Permana. (2015). Kampung Naga, pengetahuan ekologi tradisional dan pelestarian keanekaragaman hayati tumbuhan. Yogyakarta: Plantaxia.

Suganda (2006) dan Sarigendyanti (2008). Dalam Permana (2015), Kampung Naga, Pengetahuan Ekologi Tradisional dan Pelestarian Keanekaragaman Hayati Tumbuhan. Yogyakarta: Plantaxia.

Tzortzy, K. (2007). Museum building design and exhibition layout: pattern of interaction, Proceedings 6th International Space Syntax Symposium, Istanbul.

Unwin, S. (1997). Analysing architecture. London: Routledge.

Westcott, J. (Eds.). (2014). Fireplace. Italy: La Biennale di Venezia/ Rem Koolhaas. 